\title{
Influence of Religious and Cultural Beliefs on Girl-Child Educational Aspiration in Nigeria
}

\author{
Osamiro Emmanuel Osagiobare \\ Department of Educational Studies and Management, Faculty of Education, \\ University of Benin, Benin City, Nigeria \\ Email:Emmanuel.osagiobare@uniben.Edu
}

\author{
Rita Osayemwenre Oronsaye \\ Department of Adult Education, Faculty of Education, University of Benin, Benin City, Nigeria \\ Email:Rita-orons@yahoo.com \\ Victor Ekwukoma \\ University of Benin, Benin City Nigeria, General Studies Department \\ Email: ekwukomavictor@yahoo.com
}

Doi:10.5901/jesr.2015.v5n2p165

\section{Abstract}

The study examined the influence of religious and cultural beliefs on girl-child educational aspiration in Nigeria. The sample for the study consisted of one hundred and eighty (180) parents randomly drawn from the six Area Councils in the FCT-Abuja. Data were collected with a questionnaire entitled "Girl-child Education and the Challenges of Religious and Cultural Beliefs Questionnaire (GECRCBQ)". The data collected were subjected to statistical analysis using the Chi-square method. Ten null hypotheses formulated were tested at .05 level of significance. The results indicated among others that early marriage and early pregnancy impede girl-child education; that girl-child education is negatively affected by the belief that if a woman is educated, she will dominate her husband, and that misunderstanding of the position of Islam on the education of girls impedes girl-child education especially in the Northern Nigeria. It was recommended inter alia that the various religious groups such as Muslim, Christian and African Traditional associations should help to teach parents the true positions of their religion on girls' education. The associations should help develop programmes that would assist parents and families in educating their daughters.

\section{Introduction}

Culture is a complex whole which includes knowledge, beliefs, arts, morals, customs and any other capabilities acquired by man as a member of the society. It is the sum total of a given society's way of life moulded and shaped by prevailing circumstances and environment (Nakpodia, 2010). Culture can also be viewed as the way of life of a social group, and it includes actions, values and beliefs that can be communicated with necessary modifications from one generation to another. Nakpodia noted that culture is made up of a list of elements. The elements of culture whether materials or nonmaterials can be taught and learnt only through interaction as members of a group. Culture is shared; that is, it is practised by a whole group of people from generation to generation (Bhaba, 1990 cite in Nakpodia, 2010). It varies from one society to another and even within the same group of people depending on certain factors such as civilization. This means that culture is not static but dynamic, and it is expressed in terms of human behaviours shared among a people, and it is learnt rather than inherited. Therefore, the fundamental aspects of culture that influence girl-child education in Nigeria include belief, values, routines and customs. Religion on the other hand, refers to the belief in the existence of a god or gods. Religious beliefs therefore encompass all the activities, sentiments and opinions connected with the worship of a deity.

Studies have shown that some religious and cultural beliefs and practices in Nigeria impact on the educational aspirations of girl-children (Onochie, 2010). For instance, certain Islamic practices prevent young girls from schooling in some northern parts of Nigeria. Idabawa $(2004$, p.5) cited in Onochie (2010) linked this malfunctioning simply to 
"misunderstanding of the position of Islam on the education of girls - largely due to lack of sufficient knowledge of Islam which makes many parents think that formal education is not meant for Muslim girls. Among some cultural groups in Nigeria, girl-children are discouraged from the fervent pursuit of formal education because of the belief that education makes women to look down on men, and that it discourages many rural men from getting married to educated women. For this reason, most rural parents are not willing to invest in the education of their female children since such investment may well inhibit their chances of getting married on time. Similarly, several researchers in Nigeria (Okojie, Chiegwe and Okpokunu, 2006 ; Idabawa, 2004; Ayodele, Popoola and Akinsola, 2006 \& Iruloh, 2008) have also shown that girls are not encouraged to stay longer in education as that may culminate in the person turning into the popular "old layer" (very old single lady) while still in the parents' home. It is a common belief especially amongst low income families that attending and staying longer in school might cause a girl not to get married as she would graduate out of school as an "old layer". Personal experience of the authors has further shown that most ladies are overwhelmed with the dread of not finding husbands if they get to a certain level of education, and if they allow prolonged education to delay them. In the northern part of Nigeria, for example, early marriage and / or early pregnancy is encouraged, and this affects the educational aspiration of the female children. It is in this light that Sandhu, Chaudhry, Akbar and Ahmad (2005) indicated that old customs, traditions, caste systems, rural community and wrongly understood religious knowledge have denied the females education in the rural places of Faisalabad, Pakistan. Bunyi (2004a) argued that it is generally believed amongst rural Kenyan families that girls' education is an unwise financial investment owing to the fact that the income accrued from it will be enjoyed only by their husbands' families with insignificant or no benefit at all for their parents' families. Bunyi's assertion is consistent with Ekwukoma's (2014) opinion that among some cultural groups in Nigeria, it is believed that investing in girl-child education is a deliberate waste of resources as it will only benefit the family into which she later gets married. The assertions of Sandhu et al, (2005) and Bunyi (2004a) give credence to the fact that the inhibition of girl-child education by certain cultural beliefs is not a peculiarity of the Nigerian society. That is, these beliefs permeate other developing societies of the world.

In addition, some rural-dwellers in Nigeria hold a cultural belief that domestic chores are the basic responsibilities of female children. It is believed that it is what God has created them to do, and so they have a special ability to do it. To such parents, domestic activities are the vocations of female children. This impression is premised on the traditional philosophy of girls as prototype mothers whose major responsibilities in life are to take care of their children and husbands. This reactionary philosophy of the responsibilities of the girl-child has heavily impacted negatively on female education. This opinion of the researchers is consistent with the assertion of Onochie (2010) that for most rural-dwelling Nigerian parents, education of female children has value to the extent that it can assist them to become responsible housekeepers; such responsibility does not require any form of higher education. Within some households, female children are engulfed in a sort of routine domestic lifestyle that is fed advertently or inadvertently by some sort of patriarchal dynamics. The female children are consequently pictured as objects of dominance whose education must end in the household domestic affairs. As a result of this belief, a majority of the girl-children are given little or no opportunity for homework and private studies. They are constrained by domestic duties most of which are stereotyped. The female children are hardly given adequate time in homes to engage in serious academic work

There is yet a belief among some parents, especially poverty-stricken parents, that it is wrong for a girl-child that has attained the age of puberty to be making financial requests on the parents. That is, they believe that she should be able to use her "natural gift" to meet her needs. Consequently, girl-children from homes where such a primitive belief subsists do pick up the career of going after men in order to get money to buy cosmetics, jewellery, dresses and meet other financial needs. On most occasions, such female children end up contracting Sexually Transmitted Diseases (STDs) or becoming pregnant at a very early age which eventually shatters their educational aspirations. There is also a belief among some cultural groups in Nigeria that an intimate discussion between parents and their children on human sexuality is a taboo. This belief prevents parents from giving their female children thorough sexuality education, and consequently, makes the female children ignorant of the possibility of becoming pregnant once menstruation has commenced. This usually results in early pregnancy which inhibits the girl-child's educational aspiration.

\section{Statement of the Problem}

The problem that gave rise to this study is the age long religious and cultural beliefs, in some segments of the Nigerian society, which impede the girl-child's access to quality formal education. These beliefs have had very serious implications on how many families especially in rural areas perceive the education of their female children. Suffice to say that most of these beliefs are grounded on misconceptions and prejudice. What then are these beliefs that impede girl-child 
education? How do these beliefs negatively impact on the educational aspiration of the girl-child?

\section{Objectives of the Study}

This study was carried out to:

(i) Determine whether early marriage impedes girl-child education

(ii) Determine whether early pregnancy impedes girl-child education

(iii) X-ray some of the religious and cultural beliefs that impede the educational aspirations of girl-children in Nigeria, and consequently make relevant recommendations to correct the misconceptions upon which such beliefs are grounded.

\section{Significance of the Study}

The study will be significantly useful to governments at all levels, religious, socio-cultural and educational organisations through the provision of relevant information and strategies for disabusing many citizens of beliefs that impede girl-child education in Nigeria. Furthermore, students, scholars and researchers who may be interested in related studies will find the study handy for literature review.

\section{Hypotheses}

i. Early marriage does not significantly impede girl-child education

ii. Early pregnancy does not significantly impedes girl-child education

iii. The belief that if a woman is very educated, she will dominate her husband does not significantly impede girlchild education

iv. Misunderstanding of the position of Islam on the education of girls does not significantly impede girl-child education in the Northern Nigeria.

v. Some persons do not believe that women are less competent than men and less worthy to be given formal education.

vi. The cultural belief that the kitchen is the highest and best place a woman can function does not significantly impede girl-child education.

vii. Some cultural groups do not believe that it is a taboo for parents to discuss human sexuality with their children and this negatively affects the education of the girl-child

viii. The opinion of some parents that female children that have attained puberty age are to cater for their financial needs does not negatively affect the educational aspiration of the girl-child

ix. The cultural belief that domestic chores are the basic responsibilities of female children does not significantly impede the educational aspiration of the girl-child.

$x$. The proportion of respondents that will agree that some parents do not invest in the education of their female children because they believe they will not benefit from it will not significantly vary from the proportion of those who will disagree.

\section{Methodology}

\subsection{Research Design}

A survey research design was adopted for this study. This design was adopted because the researchers collected and analysed data from only a few subjects considered to be representative of the entire population.

\subsection{Population}

The population for the study comprises all the parents in the Federal Capital Territory - Abuja. 


\subsection{Sample}

A sample of two hundred and eighty parents was randomly selected from the six Area Councils (Abuja Municipal Area Council, Kwali Area Council, Bwari Area Council, Gwagwalada Area Council, Kuje Area Council and Abaji Area Council). Thirty parents were drawn from each of the six Area Councils.

\subsection{Instrumentation}

The instrument used for data collection was the questionnaire entitled "Girl-child Education and the Challenges of Religious and Cultural Beliefs Questionnaire, GECRCBQ". The questionnaire was face-validated by two experts in Educational Research and Statistics. The respondents were requested to rate each item on a two-point scale of Strongly Agree, Agree, Disagree and Strongly Disagree. The scale of the questionnaire was later collapsed into two: Agree and Disagree. This was necessary because of the statistical technique adopted in the study.

\subsection{Data Collection and Analysis}

One hundred and eighty copies of the questionnaire were distributed to respondents. The researchers ensured a $100 \%$ return. Data were analysed using Chi-square (One-Sample Chi-square Goodness of Fit).

\section{Results}

Tabular Summary of Chi-square Analysis of Responses to the Questionnaire Items

\begin{tabular}{|c|c|c|c|c|c|c|c|}
\hline \multirow[t]{2}{*}{ Items } & \multirow[t]{2}{*}{$\mathrm{N}$} & \multicolumn{2}{|c|}{ Responses } & \multirow[t]{2}{*}{ Df } & \multirow[t]{2}{*}{$\begin{array}{c}\mathrm{X}^{2}- \\
\text { cal }\end{array}$} & \multirow[t]{2}{*}{$\begin{array}{l}\mathrm{X}^{2}- \\
\text { table }\end{array}$} & \multirow[t]{2}{*}{ Remark } \\
\hline & & Agree & \begin{tabular}{|l|} 
Disagree \\
\end{tabular} & & & & \\
\hline & & & & & & & \\
\hline Early marriage impedes girl-child education & 180 & 150 & 30 & 1 & 80 & 3.84 & Significant \\
\hline Early pregnancy impedes girl-child education & 180 & 136 & 44 & 1 & 48 & 3.84 & Significant \\
\hline $\begin{array}{l}\text { The belief that if a woman is very educated, she will dominate her husband impedes girl- } \\
\text { child education }\end{array}$ & 180 & 130 & 50 & 1 & 36 & 3.84 & Significant \\
\hline $\begin{array}{l}\text { Misunderstanding of the position of Islam on the education of girls impedes girl-child } \\
\text { education in the Northern Nigeria. }\end{array}$ & 180 & 158 & 22 & 1 & 102 & 3.84 & Significant \\
\hline $\begin{array}{l}\text { Some persons believe that women are less competent than men and less worthy to be } \\
\text { given formal education. }\end{array}$ & 180 & 120 & 60 & 1 & 20 & 3.84 & Significant \\
\hline $\begin{array}{l}\text { The cultural belief that the kitchen is the highest and best place a woman can function } \\
\text { impedes girl-child education. }\end{array}$ & 180 & 106 & 74 & 1 & 6 & 3.84 & \\
\hline $\begin{array}{l}\text { Some cultural groups believe that it is a taboo for parents to discuss human sexuality } \\
\text { with their children and this negatively affects the education of the girl-child }\end{array}$ & 180 & 141 & 39 & 1 & 58 & 3.84 & Significant \\
\hline $\begin{array}{l}\text { The opinion of some parents that female children that have attained puberty age are to } \\
\text { cater for their financial needs negatively affects the educational aspiration of the girl-child }\end{array}$ & 180 & 112 & 68 & 1 & 10 & 3.84 & Significant \\
\hline $\begin{array}{l}\text { The cultural belief that domestic chores are the basic responsibilities of female children } \\
\text { impedes the educational aspiration of the girl-child. }\end{array}$ & 180 & 109 & 71 & 1 & 8 & 3.84 & Significant \\
\hline $\begin{array}{l}\text { Some parents do not invest in the education of their female children because they } \\
\text { believe they will not benefit from it. }\end{array}$ & 180 & 123 & 57 & 1 & 24 & 3.84 & Significant \\
\hline
\end{tabular}

Source: Authors' field work and computation

The Table above reveals that all the results are significant. That is, the proportion of those who agreed with the items of the questionnaire is significantly different and higher than the proportion of those who disagreed.

\section{Discussion of Findings}

The findings of this study revealed that early marriage impedes girl-child education; that early pregnancy is a hindrance to girl-child education; that girl-child education is negatively affected by the belief that if a woman is very educated, she will dominate her husband, and that misunderstanding of the position of Islam on the education of girls impedes girl-child 
education especially in the Northern Nigeria. These findings are consistent with Okojie et al (1996), Sandhu et al (2005), Bunyi (2004a) and Idabawa (2004) who had earlier and rightly observed that the belief that education makes women to look down on men negatively impacts on female education and that old customs, traditions, caste systems, rural community and wrongly understood religious knowledge have denied female children quality formal education.

The study further revealed that girl-child education is inhibited by some parents' belief that female children are less competent than male children and less worthy to be given formal education; that the cultural belief that the kitchen is the highest and best place a woman can function impedes girl-child education and that the belief among some cultural groups that it is a taboo for parents to have an intimate discussion on human sexuality with their children has a way of inhibiting the educational aspiration of the girl-child. These findings are in agreement with the opinions of Imogie (2010), Osagie (2008) and Ekwukoma (2014) that there is a cultural subjugation of the girl-child to the boy-child, and that the society does not view the capacities and potentials of the woman beyond the kitchen.

Lastly, the study also revealed that the belief that holds sway among some cultural groups that domestic chores are the basic responsibilities of female children is an inhibition to girl-child education; that some parents do not invest in the education of their female children because they believe they will not benefit from it, and that the notion by some parents that grown up female children are to cater for their financial needs has a way of negatively impacting on the educational aspirations of female children. These findings are consistent with the findings of several authors that gendered domestic duties and the fear of not benefiting from the investment on the education of girl-children inhibit girlchild education (Ekwukoma, 2014; Onochie, 2008; Chimombo et al, 2000; Osagie, 2008; Iruloh, 2008 and Idabawa, 2004a).

\section{Conclusion and Recommendations}

This study has clearly shown how religious and cultural beliefs negatively impact on girl-child education in Nigeria. Most of the beliefs identified in the study are grounded on misconceptions that stem from the people's culturally conservative conceptualization of girl-child education as a mere means of acquiring knowledge for domestic relevance. To correct these misconceptions, all hands must be on deck. It is to this end that the following recommendations were made:

- The media including the television, print-media and radio should help to design enlightenment programmes in local languages as familiar as possible that will not only help to capture parents' interests in educating their children, but also help to disabuse them of the constricting misconceptions and beliefs that are inhibitions to girl-child education.

- The various religious groups such as Muslim, Christian and African Traditional associations should help to teach parents the true positions of their religion on girls' education. The associations should help develop programmes that would assist parents and families in educating their daughters.

\section{References}

Ayodele, J. B, Popoola, A. A and Akinsola, M. K. (2006). Gender analysis of students' enrolment and academic staff in the University of Ado-Ekiti, Nigeria: Implication for women emancipation. The African Symposium, 6 (3 and 4), 47-55.

Bhaba, H.K. (1990). Nation and Narration (London: Routledge). In Nakpodia, E.D. (2010).Culture and curriculum development in Nigerian schools. African Journal of History and Culture, 2(1), 1-9.

Bunyi, G. W. (2004a). Gender disparities in higher education in Kenya: Nature, extent and the way forward. The African Symposium, 4 (1), 43-62.

Chimombo, J, Chibwanna, M, Dzimbadzi, C, Kadzamira, E, Kunkwenzu, E, Kunje, D and Namphota D. (2000). Classroom, school and home factors that negatively affect girls' education in Malawi. Malawi : CERT.

Ekwukoma, V. (2014). Effects of family characteristics on the education of the girl-child. A PhD seminar paper presented in the Faculty of Education, University of Benin, 23rd of July.

Idabawa, S. A. (2004). On some socio-cultural determinants of girsl' involment in education in Nigeria. The African Symposium, 4 (1), 49. In Onochie, C. I. O (2010). Guilty or not guilty? How Nigerian families impede the aspirations of Nigerian girls for higher education. US-China Education Review, 7 (6), 16-31.

Imogie, A. O. (2010). Overcoming hurdles of stereotypes about sex and leadership. Benin Journal of Gender Studies, 2 (1), 33-41

Iruloh, B. N. (2008). Socio-psychological factors influencing the educational aspirations of married women in Rivers State, Nigeria. Nigerian Journal of Guidance and Counselling, 13 (1), 92-108.

Nakpodia, E.D. (2010). Culture and curriculum development in Nigerian schools. African Journal of History and Culture, 2(1), 1-9.

Okojie, C. E. E, Chiegwe, O and Okpokunu, E. (1996). Gender gap in access to education in Nigeria: Focus group discussion with adult men and women. Kenya: Academy Science Publishers. 
Onochie, C. I. O (2010). Guilty or not guilty? How Nigerian families impede the aspirations of Nigerian girls for higher education. USChina Education Review, 7 (6), 16-31.

Osagie, R. O (2008). Investment in girl-child and women education. Benin Journal of Gender Studies, 1 (1), 55-65.

Sandhu, T. A; Chandhry, A; Akbar N and Ahmad, I. (2005). Effects of socio-economic factors on the female education in rural areas of Faisalabad (Pakistan). Journal of agriculture and social sciences, 1 (1), 41-42. 